\title{
Heuristika dalam Pendidikan Karakter Manusia Toraja Tradisional
}

\author{
Rannu Sanderan \\ Institut Agama Kristen Negeri Toraja \\ rannusan@gmail.com
}

DOI: https://doi.org/10.34307/b.v3i2.213

\begin{abstract}
Along this article, some reflection shall be presented, the social and cultural education that shaped the traditional character of Torajan people. The aim of this study is going to show that education is not just a formal institution or merely an intellectual exercise but also requires a good deal with heuristic effort. Education is not worthy of the name if it is not supported by by character building. This research is the Torajan depiction of wisdom, which is pointed to show how they treat their quality of thinking and to keep growing their quality of life by using culture as a medium of heuristic.
\end{abstract}

Keyword: education, heuristics, toraja, traditional,

\begin{abstract}
Abstrak: Kajian dalam tulisan ini hendak memaparkan beberapa refleksi sebagai hasil riset yang meneliti kearifan sosial dan pendidikan melalui budaya yang telah membentuk karakter masyarakat Toraja tradisional. Tujuan dari penelitian ini adalah untuk menunjukkan bahwa pendidikan bukan sekadar institusi pendidikan belaka atau tidak hanya sekedar latihan intelektual saja tetapi juga membutuhkan upaya heuristik yang baik. Pendidikan belum pantas disebut pendidikan apabila mengabaikan pembentukan karakter. Penelitian ini adalah penggambaran kebijaksanaan orang Toraja tradisional, yang menunjukkan bagaimana mereka merawat kualitas berpikir serta pertumbuhan kualitas hidup mereka dengan mendayagunakan kultur sebagai medium heuristika.
\end{abstract}

Kata kunci: heuristika, pendidikan, toraja, tradisional,

\begin{tabular}{llll}
\hline Article History : & Received: 20-10-2020 Revised: $15-20-2020 \quad$ Accepted:15-20-2020
\end{tabular}

\section{Pendahuluan}

Peradaban manusia Toraja sudah ada jauh hari sebelum datangnya institusi sekolah. Mereka tumbuh dan berkembang secara tradisional, dengan norma dan tatanan sosial yang melahirkan entitas budaya serta identitasnya. Budaya mereka merupakan hasil olah rasa dan karsa menjadi daya tarik bagi berbagai pihak dari luar entah untuk diteliti, maupun dalam tujuan publikasi dan dokumentasi. Kehidupan dan budaya orang Toraja tersebut menggambarkan kualitas berpikir dan kualitas hidup mereka. 
Masalah riset yakni entitas budaya serta identitasnya menjadi obyek yang memerlukan upaya pencarian secara ilmiah. Bagi khalayak orang Toraja, baik kelompok tradisional mapun kaum modernis, pencarian identitas mereka berkaitan langsung dengan teritori (kampung atau tondok). Pada pihak lain, ada sebagian besar lainnya yang meneguhkan jati dirinya bertumpu pada satu Klan yang berbasis pada satu Tongkonan. Jadi bagi sebagian orang Toraja, Tongkonan-lah yang menjadi pembobot atau penentu kapasitas individu.

Persoalan identitas dalam budaya ini melahirkan pertanyaan, bagaimana orang Toraja menghidupi pendidikan karakter sehingga tumbuh menjadi manusia yang dewasa dan berbudaya? Hal ini menjadi penting sebab identitas tongkonan dari seseorang menjadi standar pengakuan sosial bagi eksistensi dirinya sebagai manusia Toraja. Persoalan psikokultural yang lain adalah adanya sebentuk proyeksi kehidupan manusia Toraja yaitu kehidupan "di sana", sebab orang Toraja memahami kehidupan kini merupakan gambaran dari kehidupan kelak (das sollen). Dalam rangka tumbuh kembangnya pendidikan karakter manusia Toraja tradisional, acapkali spirit eskatologis ini berperan dalam heuristika pendidikan orang Toraja, kendati secara praktikal masih samar-samar.

Kendatipun tongkonan dipahami parsial dan dangkal yakni sekadar bangunan rumah tradisional saja, namun pasang surut berbudaya mereka ini menarik untuk dicari tahu, hingga bisa membentuk satu entitas budaya lokal yang perennial. Tanpa pengajaran institusioal formal, namun secara dinamis orang Toraja bisa bertumbuh dalam karakter luhur, sangup beradaptasi dan bertahan di tengah pengaruh identitas budaya baru. Wacana inilah yang diletakkan sebagai probelmatika yang akan diteliti dan hendak ditemukenali.

Kendati ideologi tersebut berada dalam wilayah abstrak, namun diduga telah menjadi prinsip yang telah menuntun dinamika perkembanga peradaban mereka. Aspek lain yang memukau adalah transmisi nilai budaya yang bersifat lisan, bagi peneliti budaya hal ini menjadi keasyikan tersendiri untuk terus digali. Problem yang menantang adalah di tengah gempuran kultur kolonial yang berbudaya teks tulis, hingga dampak pandemi yang meniadakan praktik klasik pengajaran sekolah, maka budaya Toraja masih sanggup beradaptasi dalam kelisanannya mendidik anak-anak atau keturunannya. Bagaimana polanya sehingga mereka masih eksis, tumbuh dalam kemutakhiran sekaligus tetap hidup dalam tradisi? Seperti apakah dinamika pendidikan yang membentuk mereka, sehingga tidak dapat dipandang sebelah mata? Bagaimana gereja (pendidikan Kristen) memandang realita ini agar dapat belajar dan menimba pengalaman demi pengarusutamaan pendidikan anak yang berdaya dukung? 


\section{Metode Penelitian}

Kajian ini berada dalam domain kebudayaan masyarakat yang berfokus pada riset dalam kajian kearifan lokal. Jadi yang hendak dibangun dalam diskursus ini adalah dengan pertama-tama melakukan studi kepustakaan terhadap berbagai bentuk kebijaksanaan masyarakat setempat yang terkait dengan konteks lokalitas, pengalaman komunitas kecil masyarakat. Dengan "kebijaksanaan" yang di dalamnya mencakup ritus, mitologi, teks kuno, simbolisme, relasi manusia dengan sesamanya, alam dan Tuhan. ${ }^{1}$ Dan secara tradisional, dalam konteks Indonesia, keluarga merupakan tempat pendidikan yang paling organik, harmoni dan tenang dalam satu kelompok masyarakat. ${ }^{2}$ Budaya kelisanan orang Toraja menjadi salah satu medium untuk melatih anak-anak untuk menghadapi persoalan secara lumrah (problem posing), dan juga serempak dengan itu menyelesaikan suatu masalah (problem solving) dengan kreatif. Inilah sebabnya heuristika dipilih sebagai cara pandang untuk melihat kecerdasan lokal orang Toraja tradisional/primitif. Akan diuraikan bagaimana proses heuristik

Sambil memanfaatkan berbagai literatur buku kekristenan, jurnal terbaru, peneliti pun hendak mendayagunakan berbagai sumber audio visual (multimedia) sebagai sumber-sumber yang memberi kontribusi teoritik. Berbagai referensi data yang digunakan dalam penelitian ini diadaptasi dan/atau diambil dari buku berkategori pendidikan, dan lebih spesifik pada pustaka yang berkontent budaya serta kearifan lokal. ${ }^{3}$ Selanjutnya penelitian ini kemudian diolah secara dinamis dan kreatif oleh peneliti. Data yang dikumpul akan diperoleh melalui cara pengamatan langsung (observasi dan live in study), juga didukung dengan wawancara. Kemudian hasilnya disajikan dengan analisa kualitatif yang berguna menunjukkan keterhubungan antarfenomena masalah penelitian, puncaknya membantu pemangku kepentingan (gereja, peneliti, pendidik, pemerintah) dalam menemukan makna agar dapat direlevansikan dengan konteks kebutuhan masa kini.

\section{Hasil dan Pembahasan}

\section{Tongkonan sebagai Komunitas Belajar}

Gereja Toraja sendiri sebagai stakeholder terbesar, memakai Tongkongan sebagai simbolisasi persekutuan pada jenjang sinodal, yakni Tongkonan Sangulele. Untuk menolong pembaca melihat prinsip dan hakikat keberadaan tongkonan tersebut

\footnotetext{
${ }^{1}$ FX. E. Armada Riyanto CM, Metodologi, Pemantik \& Anatomi Riset Filosofis Teologis (Malang: Penerbit Widya Sasana Publication, 2020). 16

2 Tod Jones, Kebudayaan dan Kekuasaan di Indonesia: Kebijakan Budaya Selama Abad Ke 20 Hingga Era Reformasi (Jakarta: Yayasan Pustaka Obor Indonesia, 2015). 147-148

${ }^{3}$ Murniati Agustian, Pendidikan Multikultural (Jakarta: Penerbit Unika Atma Jaya Jakarta, 2019). 46, 110
} 
maka di bawah ini hendak diurai dimensi ekklesia dari tongkonan hingga fungsinya sebagai media transmisi nilai lintas generasi.

Realitas sosial dan fenomena empirik yang terlihat secara langsung sehubungan dengan budaya orang Toraja adalah simbol sosial kemasyarakatan terkecil yakni rumah. Rumah dalam arti sempit, yaitu Tongkonan merupakan konstruksi budaya (fisikal belaka) yang didirikan oleh nenek moyang mereka. Dalam makna yang lebih luas maka tongkonan dalam hal ini dijadikan simbol komunitas genealogis antara seorang insan atau anak Tongkonan dengan leluhurnya bersama rumpun keluarga serta keturunanya, atau menurut Theo Kobong, Tongkonan adalah lambang dan pusat pa'rapuan ${ }^{4}$ (rumpun keluarga). Keberadaan anggota Tongkonan mensyaratkan harmoni (karapasan) dalam memelihara persekutuan (kasiturusan) dari seluruh pendiri tongkonan karena demikianlah nilai ontologi dan norma dasar Tongkonan, yang dikenal daam ungkapan toma'raputallang, tosangkaponan ao' (raputallang=rumpun bambu)

Terminologi Tongkonan diambil dari kata dasar"tongkon" yang berarti duduk. Dalam makna yang dipahami lebih luas adalah bahwa tongkonan itu sendiri memang merupakan lokasi, tempat (assembly atau convention hall, synode dalam bahasa Gerika) dalam rangka mendengar serta tempat untuk 'duduk' bersama membicarakan serta mengambil keputusan demi penyelesaian setiap masalah yang penting sehubungan citra tongkonan $^{5}$. Kemudian, dari dimensi fisik bangunan kata tongkon juga dipakai untuk elemen patongkon atau tiang-tiang rumah yang berdiri tegak untuk mendirikan bangunan tongkonan itu sendirí6. Jadi secara inheren di dalam tongkonan itu sendiri terkandung nilai persekutuan, kombongan atau kasiturusan. Sebab segala hal yang disepakati (menjadi kada kalebu=permufakatan) dalam komunitas tongkonan pada akhirnya menjadi kasiturusan, yang selanjutnya dipercaya mendatangkan kebahagiaan (paria) dan damai sejahtera (rongko').

Manusia Toraja (dalam pengertian primitif), sejarah dilihat sebagai pengungkapan ontologi-mistis yang terus menerus mengulangi tindakan primordial secara sadar melalui pemaknaan isyarat maupun paradigma (seperti siklus spiral). Sejarah diatur oleh arketipe, maksudnya tindakan hanya dilakukan sejauh meniru dan mengulangi arketipe ${ }^{7}$ (misalnya konsepsi: dandanan sangka'-Toraja, ataupun yurisprudensi dalam filsafat hukum), karena segala tindakan yang tidak memiliki pola dasar dianggap "tanpa makna". Bagi kaum modernis, mungkin menganggap bahwa spritualitas kuno ini akan membuat masyarakat tradisional tidak mengenali diri sendiri,

\footnotetext{
${ }^{4}$ Theodorus Kobong, Injil dan Tongkonan: inkarnasi, kontekstualisasi, transformasi (Jakarta: BPK Gunung Mulia, 2008). 86-89

${ }^{5}$ L. T. Tangdilintin, Toraja Dan Kebudayaannya (Tana Toraja: Yayasan Lepongan Bulan, 1975). 116

${ }^{6}$ Markus Bamban, Ma'kombongan, Desember 2019.

${ }^{7}$ Octavio Paz, Levi-Strauss ; Empu Antropologi Struktural, trans. Landung Simatupang (Yogyakarta: LKiS Pelangi Aksara, 1997). 101
} 
namun dalam intensitasnya sendiri terdapat otentisitas makna yang dihidupi, dikejar dan dijunjung.

Dengan demikian, dengan analogi ekklesia dalam kekristenan dapat terlihat bahwa tindakan dalam persekutuan (tongkonan) ini merupakan media fungsional terlaksananya proses transmisi nilai luhur dari generasi ke generasi. Pembinaan Jemaat dapat menemukan (tanpa harus mengadopsi langsung) bahwa ternyata di dalam komunitas tradisional seperti ini terdapat dinamika pengalaman yang mewujudkan proses pedagogi, andragogi bahkan heutagogi tanpa desain perencanaan pembelajaran klasikal seperti pembelajaran klasikal di sekolah modern. Tipe persekutuan manusia Toraja 'primitif' (dalam arti sejati, hakiki \& utama) merupakan entitas yang memperoleh kecerdasan kultural (kearifan) yang heuristik. Introduksi dasar ini dapat menjadi kecakapan dasar bagi pemerhati pendidikan Kristen ${ }^{8}$ dalam melaksanakan tugas/misi di tiap area pelayanan masing-masing.

Merujuk pada praktik pendidikan yang terjadi dalam masyarakat Israel kuno, dapat dikatakan bahwa tugas ini dipercayakan pada orangtua dan komunitas. Para ahli tidak dapat dibuktikan adanya pola pendidikan seperti institusi sekolah modern sekarang ini, namun budaya memberi pendidikan wajib dilakukan oleh orangtua Israel ${ }^{9}$. Adapun pola dan praktik pendidikan Israel kuno sebagaimana dimaksud diatas, dapat ditemukan dalam beberapa teks Alkitab, mereka harus menuturkannya atau mengomunikasikan bagi keturunan mereka demi pemeliharaan tradisi (Ul.6:6-9; 32:7; Ams. 3:1-3; 23:13-14; Kel. 12:26-27; 13:8; Mz. 78:3-7).

\section{Metode Edukasi Heuristik Manusia Tradisional Toraja}

Heuristika masyarakat Toraja tradisional ini mengejawantah dalam pendidikan eksperimental yang berbasis nilai-nilai luhur yang dinamis. Sajian hasil riset berikut menunjukkan bagaimana orang Toraja tradisional teredukasi tanpa dipengaruhi sistem pembelajaran modern dengan "algoritma rigid". Beberapa anutan pendidikan luhur

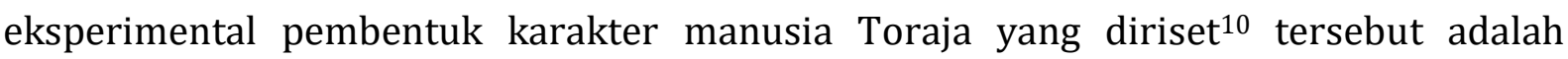
sebagai berikut:

1. Dilellenan, Kata dilellenan berasal dari kata dasar lellen, lellenan $(k b)$ yang berarti mendaduh, meninabobokkan (tt anak) ${ }^{11}$; sing a lullaby (lagu pengantar tidur), biasa juga disebut pa'tendei. Merupakan proses internalisasi pesan lewat

\footnotetext{
${ }^{8}$ Kobong, Injil dan Tongkonan. 137

${ }^{9}$ Yohanes Krismantyo Susanta, "Tradisi Pendidikan Iman Anak dalam Perjanjian Lama," BIA': Jurnal Teologi dan Pendidikan Kristen Kontekstual 2, no. 2 (December 30, 2019): 139-50, https://doi.org/10.34307/b.v2i2.127.

${ }^{10}$ Yan Piter Polandos, Heutagogi dalam edukasi kultural Toraja, 2014.

11 J Tammu and H. van der Veen, "Lellen," in Kamus Toraja - Indonesia, ed. Markus Rani (Toraja Utara: PT. Sulo dan YPKT, June 2016).
} 
lagu pengantar tidur yang di dalamnya ada lantunan syair bermakna ${ }^{12}$. Seorang anak Toraja mendapatkan pembelajaran eksperimental sejak masih bayi; jadi mereka sesungguhnya terbiasa "dihipnoterapi" dengan lagu pengantar tidur (pa'tendei) ${ }^{13}$ ketika otak anak sedang bekerja dalam gelombang theta. Dalam pa'lellenan untuk bayi, jika ia perempuan maka isi panglellenan adalah harapan akan kesuksesan dalam pekerjaan wanita, misalnya: "kasalle lao meurang, lobo' lao mekaumbu'. Sedangkan pa'lellenan untuk laki-laki ${ }^{14}$ berisi harapan agar sang anak senantiasa sukses dalam pekerjaan laki-laki misalnya dalam syair: "kasalle tang diada', lobo' papatu inaa" (harapan mengenai pertumbuhan dan perkembangannya). Atau undoloi sangbara'mu, untonda pada dadimmu (nilai harga diri ${ }^{15}$. Harapan ini juga tersirat dalam lagu pengantar tidur (pa'tendei) yang berbunyi: ...Lobo' manarang ussaro mase, anna passakkeko puang, muala leko'na sugi'ma'tadilokna eanan, naporannu rapummu, naposende sangtondokmu dan seterusnya. Artinya tumbuhlah besar, pandai mencari nafkah agar Tuhan memberkatimu, sehingga engkau kaya menjadi harapan keluarga dan masyarakat. 16

Tindakan repetisi atau pengulangan kebiasaan ini terangkai menjadi pengalaman dan membentuk habit pribadi yang selanjutnya bertumbuh menjadi budaya pribadi maupun budaya keluarga dalam suatu Tongkonan. Dengan demikian proses pemelajaran eksperimental melalui pewarisan nilai karakter dan moral dapat ditanam dan dipupuk dalam tradisi dan dinamika budaya Tongkonan, khususnya kebiasaan ma'lellenan. Pengajaran sedemikian ini yang terus-menerus menetaskan sebentuk identitas diri yang mulai terbentuk, lantas ideologi budaya ketorajaan tertanam kuat dan terus bertumbuh dan berbuah. Dengan demikian dapat dikatakan pola asuh tradisional bagi anak Tongkonan sejatinya bisa menghasilkan kecakapan kultural dan individu yang berkarakter.

2. Dikaloli' nama'perangi Frase dikaloli' nama'perangi, berasal dari kata dasar kaloli' dan perangi. Kaloli' berarti mengundang, selamanya dan ke manapun dibawa; kaloli'i: bawa ke selamanya bersama-sama; mekaloli': mengundang kita; selalu membawa ke mana-mana; sikaloli': selalu besama-sama; selalu

\footnotetext{
${ }^{12}$ Poppy Savitri, Fungsi lagu pengantar tidur anak dalam proses sosialisasi anak (Jakarta: Departemen Pendidikan dan Kebudayaan, Direktorat Jenderal Kebudayaan, Direktorat Sejarah Dan Nilai Tradisional, Proyek Inventarisasi dan Pembinaan Nilai-Nilai Budaya, 1991). 3

${ }^{13}$ Y.A. Sarira, Aluk Rambu Solo' (Rantepao: Pusbang Gereja Toraja, 1996). 15

${ }^{14}$ Kondisi gelombang otak yang dialami manusia ketika mengantuk dan mulai masuk alam bawah sadar (hampir tertidur)

${ }^{15}$ Th. Kobong, ed., Manusia Toraja: Dari Mana - Bagaimana - Kemana, Seri Institut Teologia (Tangmentoe: Institut Teologia Gereja Toraja, 1983). 26

${ }^{16}$ Paranoan, Prof. Dra. Ny. M.S., Aluk Rambu Solo' Upacara Kematian Orang Toraja Analisis Psikososio Kultural (Makassar, n.d.). 14
} 
berdampingan ke manapun perginya. Ma'perangi berasal dari kata dasar rangi: dengar, dalam hal kajian ini dihubungkan dengan kemapuan auditif seorang anak. Jadi dikaloli' anna ma'perangi bermakna: seorang anak yang selalu dibawa orangtunya ke manapun pergi akan lebih banyak mendengar pengajaran dan kata-kata dari orangtua, maupun mendengar percakapaan antar orangtua lain. Anak-anak kecil biasa terdidik dalam kasih sayang diluang sambu'(dalam kehangatan sarung ayahnya) atau naluang dodo misalnya oleh ibunya. Proses ini merupakan sebuah praksis di mana seorang anak dikutsertakan setiap saat ${ }^{17}$ dan ke tiap tempat di mana ia dapat mengamati tutur, laku dan giat orangtuanya.Transmisi nilai karena dikaloli' membuat anak kecil Toraja mudah mendengar (ma'perangi) lalu menerima dan menginternalisir nilai-nilai pengajaran orangtuanya. Kecerdasan mendengar seorang anak Toraja berkemampuan auditif secara tradisional akan berkembang dan menjadi salah satu tool pengungkit kecakapan seorang anak. Sehingga secara sistemik menciptakan pribadi yang utuh dalam sekalipun tidak mendapatkan asesmen formal dari institusi pendidikan.

Prinsip edukasi eksperimental ${ }^{18}$ yang sangat humanis dalam hal ini adalah seorang anak belajar dalam ketenangan dan kenyamanan penuh (tanpa rasa was-was atau tanpa kekuatiran sedikitpun) karena merasa terlindungi dalam dekapan orangtuanya, walaupun berada dalam komunitas percakapan antar orang dewasa. Citra diri mulai tergambar sedikit demi sedikit bahwa ia (anak) adalah pemimpin, pengambil keputusan, atau yang akan didengar.

Perihal nilai dikaloli' na ma'perangi, jika tetap dilaksanakan, selanjutnya akan terwariskan lagi bagi keturunan anak-anak Toraja secara terus-menerus, dari generasi ke generasi secara habitual.

3. Diuleleanni (dikisahi) Dari kata dasar ulele; menceritakan; cerita; ulelean pare: cerita dongeng yang biasa diceritakan pada waktu padi di sawah telah mulai menunjukkan bulirnya). Dalam kata ulelean tangtongandika (adakah cerita yang tidak benar? Maksudnya cerita yang sungguh benar). ${ }^{19}$ Orang Toraja tradisional memunyai kebiasaan untuk mendongeng bagi anak-anaknya saat berkumpul. Dongeng-dongeng yang diceritakan berisi pesan-pesan moral yang disampaikan secara halus dan tertenun dalam cerita (sistematis). Menurut Wahyu Fitirani, dongeng bermanfaat untuk membentuk karakter, (fairy tales in the formation of children's character) dan lebih lanjut menunjukkan adanya karakter positif dan

\footnotetext{
${ }^{17}$ tim Penulis Ikatan Psikologi Perkembangan Indonesia, Bunga Rampai Psikologi Perkembangan: Memahami Dinamika Perkembangan Anak (Sidoarjo: Zifatama Jawara, 2019). 241

${ }^{18}$ H. A. R. Tilaar, Kebijakan pendidikan: pengantar untuk memahami kebijakan pendidikan dan kebijakan pendidikan sebagai kebijakan publik (Yogyakarta: Pustaka Pelajar, 2008). 256

19 J Tammu and H. van der Veen, "Ulele," in Kamus Toraja - Indonesia, ed. Markus Rani (Toraja Utara: PT. Sulo dan YPKT, June 2016).
} 
membentuk nilai budaya nasionalis. ${ }^{20}$ Ada berbagai kisah yang menarik dalam dongeng ini dan ada pula bermacam-macam alur yang berbeda-beda pula, menjadi kekayaan kisah dan nilai bagi penyimak atau pendengarnya.

Seorang anak Toraja biasanya akan meminta kepada orang yang lebih dewasa (misalnya ayah, ibu, kakek, nenek, atau kakaknya) untuk menceritakan suatu dongeng kepadanya di waktu-waktu senggang. Atau seringpula insiatif bercerita datang langsung dari orang yang lebih tua. Biasanya juga terdapat satu cerita yang sama, namun cerita itu disampaikan dengan beberapa variasi yang berbeda, karena cerita tersebut bersifat lisan, hal ini mengakibatkan penerimaan setiap orang berbeda sehingga penyampaian ulangnya mungkin berbeda pula. Itulah sebabnya ulelean pare praktis akan mengalami pengulangan, namun selalu menarik karena senantiasa disampaikan dengan improvisasi yang berbeda dari subyek pencerita khususnya pola narasinya (alur/plot, tokoh, tempat, waktu dll). Narasi jauh lebih menarik dan berfungsi kuat membentuk karakter dalam diri seorang anak. Itu sebabnya, ceritera, dongeng, drama, sinema dan yang lain lebih sanggup "menghipnotis" para penyimaknya hingga waktu tak terasa sudah lama. Umumnya otak anak sudah berada pada gelombang Theta, di mana proses intenalisasi nilai paling efektif dan ampuh. Karena pada saat ini gerbang alam bawah sadar mulai terbuka sehingga instruksi atau kegiatan dapat dilakukan dengan mudah. ${ }^{21}$ Pengisahan melalui sebuah "ulelean" dapat menyapa dimensi intuitif dan relung batin seseorang. dengan kata lain, ulelean memiliki kemungkinan untuk mengisi kekosongan spiritualitas individu. Kisah atau narasi lebih menarik bagi manusia, tanpa batasan umur. Dengan kata lain, manusia adalah makhluk naratif. Ceramah dan khotbah doktriner pada batas waktu tertentu berguna, namun akhirnya pupus. Hal ini terbukti karena tidak ada seorangpun yang dapat mengingat (apalagi menghapal) sebuah khotbah. Sementara, seorang anak kecil saja ternyata sudah dapat menceritakan ulang dongeng atau suatu narasi (ulelean) yang telah ia simak, bahkan dengan modifikasi dan improvisasinya sendiri. Pembatinan dan pengulangan ulelean ini akan menanamkan prinsip dan karakter yang akan menjadi pandu hidupnya secara tradisional. Ciri khas pada manusia adalah seseorang lebih banyak dipengaruhi (lebih mudah dibentuk) oleh cerita daripada data, definisi, atau konsep abstrak.

Pada dasarnya, karakter mulai dibicarakan melalui pengisahan. Dalam suatu pengisahan/narasi, seseorang dapat saja berganti peran atau fungsi; sebagai

\footnotetext{
${ }^{20}$ Wahyu Fitriani, “Dongeng Dapat Membentuk Karakter Anak Menuju Budi Pekerti Yang Luhur," Jurnal Review Pendidikan Dan Pengajaran 2, no. 1 (June 12, 2019): 178-83.

${ }^{21}$ Denok Sunarsi, Dinamika Dan Perkembangan Hypnotherapy Dalam Perspektif Interdisipliner, ed. Achmad Rozi (Banten: Runzune Sapta Konsultan, 2020), http://eprints.unpam.ac.id/8620/.
} 
pengarang, pelaku, tokoh protagonis, antagonis, penanggap langsung maupun tidak langsung, pendengar sejati, pendengar tidak langsung, komentator, dll. Seseorang dapat menjadi penulis sekaligus pembaca kisah kehidupan dirinya sendiri.

Artinya, seorang anak dapat memiliki nilai hidup dan karakter justru dengan bantuan kebiasaan "diuleleanni".

4. Mentiro Dari kata dasar tiro: melihat, memandang, menilik, mengamati; tiro toyang: melihat dari jauh. Mentiro dalam hal ini lebih merujuk pada proses mengamati / atau research dan observasi. Secara praktis, kecakapan mentiro satu subyek terkesan pasif, namun kemampuan visual seorang anak Toraja akan terasah dengan baik apabila menggunakan penuh kemampuan mentiro ini. Berawal dari kecakapan visual, selanjutnya akan menjadi keterampilan yang berpengaruh pada pengasahan patiro penaanna: penglihatan hatinya, lantas melalu hal itu akan melatih seorang anak dapat mengemukakan pendapatnya (kedenni patiromatammu=bila ada yang kau amati).

Mentiro juga akan meningkatkan kecakapan membandingkan (komparasi atau rasio) dari seorang anak. Bagi seorang anak yang memiliki potensi kepemimpinan maka jika ia diminta: "patiroi melo" maka ia akan belajar memimpin kepada kebaikan, sebab ia akan berusaha belajar membukakan jalan untuk perbaikan (nasib bersama sekaligus kedudukannya sendiri).

Mentiro dapat melelahkan, tetapi dapat pula menarik; namun seseorang selalu mendapat input/info yang bersifat display. Seperti yang telah diuraikan di atas bahwa otak manusia lebih banyak bekerja melalui gambar (visualisasi).

Bagi anak yang memiliki kemampuan visual, maka sesungguhnya bagi tipe anak seperti itu (dalam pola pendidikan modern) sejatinya sudah mendapat tempat dan pemolaan dalam konteks masyarakat tradisional Toraja. Dengan demikian, anak bisa terlatih untuk memiliki keterampilan mengamati (observasi) suatu fenomena atau sebuah fakta.

5. Ma'peolai (meniru/mengimitasi model, mengikuti jejak). Dari kata dasar "ola": berjalan melalui, menjalani menempuh (jalan); mengejakan (pekerjaan); mengalami (sesuatu hal); menanggung (sesuatu yang perlu); menyokong atau menyumbang biaya pesta/upacara, dst. Mengkaola: menurut dengan sungguhsungguh, suka menurut dengan hati yang lemah lembut, patuh, taat. Umpengkaolai kamanarangan: menurut kepandaian, berusaha mendapat kepandaian. ${ }^{22}$ Makna hakiki dari Ma'peolai lebih merujuk pada konsep peneladanan, melalui proses peniruan atau pengimitasian dari sesuatu yang diidealkan (das sollen). Artinya, keteladanan dapat memupuk pertumbuhan

${ }^{22} \mathrm{~J}$ Tammu and H. van der Veen, "Ola," in Kamus Toraja - Indonesia (Toraja Utara: PT. Sulo dan YPKT, June 2016). 
kepribadian dan karakter jika seorang anak telah memiliki modal dalam bentuk minat atau antusiasme. Sebagai salah satu aspek psikis yang penting, minat muncul dari dalam pikiran dan hati seseorang untuk mendorong hasrat dalam melakukan sesuatu (passion).

Peneladanan berpadanan dengan konsep menyimak/mengamati dan menirukan sebagai salah satu aspek teori pendidikan agama kristen. (proses dan cara belajar anak dalam masa pertumbuhan). Hampir semua ahli pendidikan sepakat bahwa keteladanan dan menirukan adalah alat yang paling ampuh untuk mengajarkan iman secara berulang-ulang. Misalnya, C. Ellis Nelson mengatkan bahwa iman yang otentik berdiam dalam persekutuan orang pecaya dan selanjutnya diteladankan bagi setiap anggota-anggota persekutuan yang baru. ${ }^{23}$ Jadi ma'peolai bukan hanya melulu pada aspek motorik, namun bagi masyarakat tradisional Toraja, kehidupan rohani juga terbatinkan dan tumbuh melalui proses ma'peolai. (walau sesungguhnya manusia Toraja tidak memisahkan kehidupan profan maupun transenden).

Ma'peolai sendiri dapat dikatakan sebagai naluri alamiah yang ada dalam diri masyarakat tradisional, termasuk manusia Toraja. Segala aktivitas budaya dan kehidupan selalu dilihat sebagai rangkaian periodik yang berulang (siklis). Artinya, setiap kejadian, peristiwa dan kehidupan kekinian selalu memiliki rujukan atau pola jejak yang sama dalam sebuah rangkaian pengulangan. Konsekuensinya ma'peolai menjadi keharusan agar kehidupan masa kini tidak bias atau tidak bertentangan dengan pola yang serupa sebelumnya. Dalam fase ini amat dibutuhkan fungsi eksemplari yang baik dari orang yang lebih tua, karena bisa saja keteladanan mereka akan "berbicara" lebih keras dari pada didikan verbal. ${ }^{24}$

Selanjutnya pola penjejakan secara kultural diejawantahkan dalam praksis yakni dipabiasa: dibiasakan melalui pengulangan-repetisi. Praksis hidup dari satu individu terbentuk melalui kebiasaan, itulah inti budaya. Maka budaya akan terus merevitalisasi dirinya dalam pola yang sejenis, dalam hal ini budaya bukan menciptakan hal yang baru, namun mengulangi dan membiasakan pengulangan tersebut.

Proses belajar dari seorang anak Toraja tradisional tentu akan melalui pola dipaolai anna dipabiasa. Praksis ini ternyata juga dianut oleh teori pendidikan modern, dengan berbagai nama dan modifikasi sendiri. Bahwa seluruh eksistensi

\footnotetext{
${ }^{23}$ Carl Ellis Nelson, Where Faith Begins (Louiseville: John Knox Press, 1971).

${ }^{24}$ Rannu Sanderan, Exemplary, Menemukan Kunci Pendidikan Iman Bagi Anak Dalam Keluarga Dan Pembelajaran Agama Di Sekolah (Tana Toraja: STAKN Toraja, 2016).
} 
kehidupanya mengandung nilai mitis ontologis, sehingga dengannya segala tindakan sebelumnya menjadi prototipe dari tindakan sekarang25.

6. Dilamba' dari kata dasar lamba': 1) mengumbar; 2 sudah bebas pergi bermain sendiri (tentang anak yang sudah besar sedikit) ${ }^{26}$; dibiarkan bebas menghadapi tantangan tanpa harus diawasi secara ketat, berlebihan dan intimidatif.

Menjadi eksploratif bukan dalam konotasi bebas liar, tetapi kebebasan yang dibatasi oleh kebebasan orang lain. Kebebasan dalam menjelajah dapat berlangsung dalam proses bersosialiasi dan disiplin yang diberikan orangtua kepada anak, tentunya dilamba' dalam hal ini bernuansa membimbing tanpa mengekang namun justru dengan kasih sayang.

Ronald W. Leigh, mengatakan: kebebasan remaja sampai pada taraf tertentu harus dipandang sebagai suatu hal yang positif. Apabila remaja tidak belajar mengambil keputusannya sendiri, maka ia akan lambat menjadi dewasa. ${ }^{27}$

Khususnya bagi anak yang masih berada dalam usia remaja, karena pada masa transisi itulah mereka acapkali mengalami banyak macam perubahan dalam dirinya. Dilamba' tentu dalam perspektif pengawasan, pendampingan, pembinaan serta bimbingan sepantasnya yang amat berguna bagi pembentukan karakter, moral dan kepribadian seorang anak.

Dilamba' pada akhirnya bukan hanya melahirkan karakter dan kebiasaan eksploratif, namun menumbuhkan daya juang yang tangguh dari seorang anak, tatkala ia harus belajar menghadapi tantangan dalam proses dilamba' (menjelajah). Kemampuan fisiologis dan psikis dari seorang anak yang dilamba' akan berubah menjadi lebih baik dan lebih kuat.

Selanjutnya, konsekuesi seorang anak yang dilamba' adalah Matona', kata tona', artinya sudah cakap melakukan sesuatu pekerjaan karena sudah kuat (besar) sudah hampir dewasa. ${ }^{28}$ Dilamba' anna matona' bermakna dilatih untuk mandiri. Seorang anak yang dilamba' anna matona' akan tumbuh menjadi pribadi yang mandiri, sanggup mengambil keputusan dengan siap pada konsekuensinya, dewasa dalam tindakan, sportif dan pada akhirnya menjadi bijaksana/ memiliki hikmat.

Dapat disimpulkan bahwa kebebasan memiliki proyeksi penting, yakni tumbuhknya kedewasaan dan hikmat pada seorang anak. Dampak tidak langsung dari nilai ini adalah kemungkinan besar akan lahirnya seorang calon pemimpin dalam konteks Tongkonan.

\footnotetext{
${ }^{25}$ in illo tempore, ab origine

${ }^{26}$ J Tammu and H. van der Veen, "Lamba'," ed. Markus Rani (Toraja Utara: PT. Sulo dan YPKT, June 2016).

${ }^{27}$ Ronald Leigh W., Melayani Dengan Efektif (Jakarta: PT. BPK Gunung Mulia, 1996). 118

28 J Tammu and H. van der Veen, "Tona'," in Kamus Toraja - Indonesia, ed. Markus Rani (Toraja Utara: PT. Sulo dan YPKT, June 2016).
} 
7. Partisipasi langsung, bekerja tanpa imbalan (anak-anak sejak kecil sudah terlibat dalam gotong-royong), mangangka', membuka ladang. Ada perbedaan psikologi anak Toraja yang hanya mendengar dari orangtuanya (anak Toraja diaspora Papua) dengan anak Toraja yang lahir dan tumbuh besar di Toraja serta berpartisipasi langsung dalam narasi kehidupan. dengan keterlibatan dan pelibatan secara sengaja sejak dini, generasi muda Toraja memahami dan melaksanakan nilai-nilai budaya Toraja seusai dengan pemahaman masingmasing. Nilai-nilai tersebut tidak diindoktrinasi dan tidak dipaksakan namun meresap dengan pelan dan pasti ke dalam kesadaran dan hati sanubari seorang anak Toraja. Itulah sebabnya, apapun latar belakang dan setinggi apapun tingkat pendidikan orang Toraja mereka akan tetap kembali untuk melaksanakan upacara adat apabila orangtua mereka meninggal. ${ }^{29}$. Nilai gotong-royong, terbangun saat mereka terlibat langsung dalam pekerjaan-pekerjaan di sawah, misalnya disaro dan metena ${ }^{30}$. Motif utama dari gotong-royong adalah saling menolong terutama dalam pekerjaan-pekerjaan berat (umpabendan banua, umpalengka' banua) misalnya mendirikan rumah, membuka sawah atau ladang, menghadapi upacara adat, baik rambu tuka' maupun rambu solo', dan pekerjaanpekerjaan lain untuk kepentingan bersama (umpemeloi lalan).

Nilai gotong-royong, dipandang bukan atas dasar nilai ekonomis, melainkan nilai partisipasi dalam persekutuan. Tindakan memberi dipandang lebih utama dari menerima, orang yang lebih banyak memberi dipandang lebih tinggi dari pada orang yang menerima. ${ }^{31}$

Pembelajaran-pembelajaran mandiri di atas, dapat dinilai sebagai pendekatan yang integral (utuh), karena memberi peluang yang sangat besar bagi anak-anak sebagai naradidik untuk belajar dan mengalami sendiri berbagai dinamika di lingkungannya. Segala realita yang diamati anak menjadi media dialektika bebas yang membentuk karakter dalam dirinya.

\section{Pembentukan karakter}

Terbentuknya emosi dan karakter anak-anak Toraja tradisional berkaitan langsung dengan berbagai manifestasi nilai yang mereka gugu (rujuk); dan hal ini diadopsi serta ditularkan secara langsung melalui keteladanan (eksemplari), sebagaimana disebut di atas, yakni mentiro dan ma'peolai. Adapun nilai-nilai etika yang mereka hidupi langsung tersebut antara lain: mengasihi, keadilan, merasa salah, malu, berani, sabar/menahan diri, menyimak, mengajukan pendapat, bersekutu, membagi kelebihan, dll; dan semua

\footnotetext{
${ }^{29}$ Naomi Sampe, “Filosofi Kande Situka' - Analisis Teologis-Sosiofilosofis terhadap Filosofi Kande Situka'dalam Eksistensi Budaya Toraja” (Tana Toraja, STT Kibadi, 2013). 101-102

${ }^{30}$ Naomi Sampe, "Penilaian Teologis Terhadap Etika Kerja Toraja” (Tana Toraja, 2014), 32.

${ }^{31}$ Kobong, Manusia Toraja: Dari Mana - Bagaimana - Kemana. 12
} 
norma tersebut merupakan heuristika pendidikan di mana karakter akan berkembang dan berbuah.

Proses edukasi tradisional masyarakat Toraja ini pada dasarnya memberi prioritas kepada anak-anak mengenal fondasi etika, moral dan kehidupan spiritual di dalam komunitas tradisionalnya. Struktur psikokultural masyarakat tradisional Toraja berkaitan langsung dengan model-model perihidup seperti yang disebut di atas, dan berpengaruh langsung pada proses edukasi anak (heutagogi).

Tekanan utama dalam pengembangan karakter secara tradisional berangkat dari nilai luhur konteks budaya lokal. Nilai luhur tersebut mengarahkan penekanan nilai intrinsik (intangible) tentang norma dan hukum moral dalam dirinya sendiri sang anak (hati nurani) maupun bagi komunitas basis di mana ia bertumbuh.

Acapkali pengalaman langsung menarik perhatian anak, khususnya ketika seorang anak diperhadapkan pada pilihan baik atau buruk, maka pada saat yang sama ia akan dipengaruhi oleh nilai yang ditanamkan dalam setiap aktivitasnya (seperti yang diuraikan di atas). Dengan kata lain, modeling dari dinamika edukasi karakter sepatutnya diupayakan melalui cara mendampingi anak untuk mengembangkan, menguatkan dan makin memperjelas nilai karakter yang dianutnya. Keberpihakan pada anak seyogianya menjadi ideologi utama dlam pendidikan bukan terutama pada pembangunan fisik. Anak-anak mesti merdeka dalam belajar, sehingga diperoleh peserta didik yang eksploratif, kreatif dan integral. ${ }^{32}$ Pendekatan tradisional dalam kajian ini juga lebih berbasis pengalaman (eksperiental) namun segala nilai yang tertanamkan akan tumbuh secara natural lalu membentuk karakter individu bersama interaksinya dalam komunitas Tongkonan.

\section{Pembelajaran Tradisional dalam Mithos Menuju Pembentukan Ethos}

Konsep dilellenan, dikaloli' nama'perangi, diuleleanni menjadi pembelajaran manusia Toraja tradisional khususnya dalam transmisi kendati diisi dengan narasi mithos. Mitologi orang Toraja tradisional senantiasa menjadi acuan bagi interkasi kosmis secara utuh. Hal ini umum ditemukan dalam masyarakat tradisional ${ }^{33}$. Secara khusus dalam litani aluk Bua' Pare, dikisahkan bahwa sebelum nenek moyang manusia (Datu Laukku') diciptakan, Puang Matua telah menyiapkan alam semesta dan isinya, dengan menciptakan nenek moyang asal dari hewan, tumbuh-tumbuhan, besi dan segala penghuni alam lainnya. ${ }^{34}$ Masing-masing dengan sukarela telah memilih tugas dan fungsinya dalam tata kosmos. . Kemampuan mitologi sejatinya dijadikan sebagai kiblat

\footnotetext{
${ }^{32}$ Dwi Risyanto and Dyah Kumalasari, Pemikiran Y.B. Mangunwijaya Tentang Pendidikan Sekolah Dasar Di Yogyakarta Tahun 1974-1999 (Yogyakarta: Jurusan Pendidikan Sejarah Fakultas Ilmu Sosial, 2015), http://journal.student.uny.ac.id/ojs/index.php/risalah/article/viewFile/830/756.

${ }^{33}$ Walaupun Sekularisme sekarang begitu kuat melakukan agresi terhadap wilayah mitologi dari keyakinan masyarakat tradisional dengan merasionalisasi seluruh aspek mitos

${ }^{34}$ D. Panginan, Aluk Bua' Pare, trans. Y.A. Sarira, 1st ed. (Rantepao: Pusbang Gereja Toraja, 2000). 
masyarakat tradisional dalam menyelesaikan problema kehidupan sehari-hari namun pada akhirnya tergusur. Namun bentukan narasi dalam mitos telah mewariskan sikap moral dan ethos dalam diri seorang anak bahkan juga bagi warga tongkonan.

"Sikap moral" menegaskan orientasi pada norma-norma sebagai standar-standar yang harus saya ikuti. Sedangkan ethos menegaskan bahwa sikap itu adalah sikap yang sudah menetap dan biasa, sesuatu yang nyata-nyata mempengaruhi, yang menentukan bagaimana saya atau sekelompok orang mendekati dan melakukan sesuatu. Maka istilah "ethos" mengungkapkan "semangat seseorang atau sekelompok orang sejauh di dalamnya termuat tekanan-tekanan moral untuk nilai-nilai moral tertentu. Maka ethos kerja adalah sesuatu yang dimiliki atau tidak dimiliki dan yang tidak dapat dipaksa. ${ }^{35}$

Kemampuan dalam diri seorang anak Toraja tradisional turut dibentuk oleh ethos komunal. Orang-orang yang rajin dan tekun bekerja selalu dibutuhkan dan disukai dalam setiap tatanan masyarakat (tae' nabela ditumpu tu to bassa'). Reaksi yang dirasakan serta reward yang diterima oleh seorang anak membuat ia mampu membedakan sikap yang akan membaikkan diri dan kelompoknya atau sikap sebaliknya. Di samping itu kerajinan bekerja akan membuat seseorang hidup berkecukupan sehingga dapat membagikan sesuatu kepada orang lain. Seorang anak yang belajar dari pengalaman orangtuanya atau orang dewasa di sekitarnya, perlahanlahan akan membentuk etika charitably (murah hati) dalam dirinya. Setiap orang Toraja tradisional yang sejak kecil dibentuk dalam pemelajaran eksperimental dalam budaya Tongkonan kendati telah sukses, atau memiliki kelebihan harta namun selalu berusaha untuk melakukan massebokan (berbagi/berkorban).

Paham khas orang Toraja mengenai kekayaan, ialah bahwa tujuan terakhir manusia dalam membanting tulang, bekerja, mengumpulkan harta tidak bertujuan untuk dimiliki sendiri, melainkan untuk akhirnya dibagirasakan kepada sesama pada ritual mantaa dalam upacara kematiannya.

Etika komunal yang ter-didikkan sejak kecil membuat seorang warga Tongkonan tidak bisa menikmati rezeki atau berkatnya bila sendiri saja. Dapat dilihat bahwa dampak pemelajaran nilai etika dalam Tongkonan ternyata lebih berjangka panjang (long term).

Pembelajaran Etika tradisional secara eksperimental ini bahkan lebih lanjut akan membentuk seorang anak memiliki integritas diri. Kesetiaan kepada janji dan kejujuran dalam memegang janji adalah suatu kebajikan. Nilai Kesetiaan dan kejujuran memegang janji dapat diedukasikan misalnya melalui narasi tentang Dodeng, mengenai batingna

\footnotetext{
${ }^{35}$ Franz Magnis-Suseno, Berfilsafat dari konteks (Jakarta: Gramedia Pustaka Utama, 1991). 120
} 
(ratapan) Lebonna dan tindakan Paerengan untuk mewujudkan kesetiaannya. Pesan terakhir dari orang yang akan mati merupakan suatu kewajiban yang harus dipenuhi. Hal ini menyangkut kejujuran sebab pesan-pesan demikian tidak tertulis. Karena nilai kejujuran dan kesetiaan melekat dalam kehidupan masyarakat maka dalam persekutuan desa tradisionil pencurian sebenarnya tidak pernah terjadi. ${ }^{36}$ Umumnya orang Toraja tradisional setia melaksanakan pekerjaannya sehari-hari dan jujur dalam melaksanakan pekerjaan khsusunya bagi orang lain.

Dari pendekatan komunikasi semiotika orang Toraja tradisional, menunjukkan bahwa mereka juga dapat terdidik melalui makna simbol ukiran yang terdapat pada rumah tongkonan mereka. Contoh: Pa'tedong atau Pa'tikke' ukiran ini melambangkan kehidupan, kerja keras dan kemakmuran/harta benda, Pa'tikke' sebagai lambang kerja dan kemakmuran orang Toraja, diukir pada semua kayu-kayu yang berdiri pada bangunan tongkonan, yang peranannya sebagai tulang punggung dari bangunan atau ruang bangunan sehingga menjadi tempat memasang dinding (sangkinan rinding). Hal itu sehubungan dengan nilai serta arti kerja sebagai tulang punggung dari kehidupan untuk kemakmuran hidup manusia. ${ }^{37}$

Menurut Wilcox orang Toraja cukup rajin dan tekun. Dalam pengamatannya terhadap cara kerja orang Toraja ia mengatakan bahwa:

“...kadang jika saya sedang mengamati tetangga saya yang sedang bekerja, saya bertanya pada diri saya sendiri: "Apakah para pekerja Anglo-Saxon (buruh keturunan Inggris) akan bekerja sedemikian enerjik dalam suhu udara yang lebih dari 80 derajat Fahrenheit?'... saya rasa dan sangat berasalan bahwa pekerja Anglo-Saxon tidak akan mau". Bagi sebagian besar orang Toraja, memang tidak dikenal aturan kerja 8 jam perhari. Mereka justru beristirahat secukupnya saja, sebab mereka menganggap tidak pernah beristirahat adalah suatu kebodohan. Dalam melaksanakan pekerjaannya mereka bekerja keras. Berdasarkan pengamatan secara langsung tersebut, ia menulis:

“..lalu saya juga akan berkata masa bodoh dengan orang yang karena otoritas, menggeneralisasi patron mereka, padahal mereka tidak pernah melihat/mengalaminya secara langsung". ${ }^{38}$

\section{Pembelajaran Eksperimental dan Pertumbuhan Karakter}

Orang Toraja adalah makhluk komunal yang meletakkan harga dirinya dalam perskutuan dengan orang lain. Persekutuan dengan orang lain yang dimaksud adalah pertama-tama persekutuan karena hubungan kekerabatan yang disebut Tongkonan, kedua persekutuan dengan orang-orang dalam satu kampung, dalam satu wilayah

\footnotetext{
${ }^{36}$ Sarira, Aluk Rambu Solo'. 132

${ }^{37}$ Sarira. 97

${ }^{38}$ Harry Wilcox, Six Months in Sulawesi (New York, USA: New York University, 1949). 431
} 
pembagian daging ${ }^{39}$ dan wilayah adat tertentu atau lembang. Karena orang Toraja tradisional mengaitkan harga dirinya dalam hubungan dengan orang lain (etika komunal) maka satu hal yang paling dihindari atau paling ditakuti oleh orang Toraja adalah tersisih dari kelompok atau persekutuan primordialnya, yang dikenal dengan istilah: "ti'pek lan mai kasiturusan"40. Jadi, keluarnya seseorang dari persekutuan dapat membuat persekutuan tersebut tidak utuh lagi, sedangkan bagi yang bersangkutan akan menjadi pribadi dan keluarga yang terbuang kelompoknya. Itulah sebabnya nilai harga diri sangat dijunjung tinggi oleh orang Toraja, serta ditanamkan atau diajarkan sejak dini melalui keterlibatan dalam pekerjaan-pekerjaan di tengah kelompok masyarakat adat dan keluarga. Setiap anak Toraja memiliki tugas dan fungsi tertentu dalam ritus atau upacara, baik rambu tuka' maupun rambu solo'. Dalam pelaksanaan ritus, anakanak sejak kecil terdidik melalui keterlibatan langsung (live in) dengan tugas-tugas yang sesuai dengan kemampuannya, mengamati secara langsung (observasi) persiapan dan pelaksanaan ritus-ritus; merasakan secara psikis semangat kebersamaan dengan orang lain dan menerima penghargaan dalam persekutuan dengan orang lain.

Sekaitan dengan nilai harga diri tersebut, maka nilai yang senantiasa membayangi orang Toraja berperilaku di manapun ia berada adalah longko'. Kata longko' berarti malu atau segan ${ }^{41}$. Longko' mencakup rasa malu, harga diri, sekaligus juga menyangkut tenggang rasa terhadap orang lain. Suasana batin seperti ini mempengaruhi mereka untuk bersikap sopan dan hormat, serta tidak mempermalukan orang lain. Adapun budaya malu, lebih menekankan pada hormat, reputasi, nama baik, status dan gengsi diri semata.

Orang Toraja melaksanakan ritus-ritus atau upacara tradisional juga karena adanya perasaan risih atau malu baik pada kelompok maupun pada orang lain jika tidak berpartisipasi dalam persekutuan. Budaya malu membuat seseorang termotivasi untuk memberikan tenaga, waktu dan materi untuk kepentingan keluarga lain maupun kepentingan bersama. Longko' dalam pemaknaan positif membuat seseorang dapat menghindarkan diri dan kelompoknya dari perbuatan tercela. Tetapi budaya longko' dapat berubah menjadi negatif pada keadaan dimana orang memaksakan diri untuk memberikan sesuatu akibat malu pada orang banyak. Kejadiaan seperti ini sering terjadi dalam kehidupan berbudaya orang Toraja terutama yang berkaitan dengan upacara yang membutuhkan pemotongan hewan. Pemberian daging pada orang banyak tidak lagi berdasarkan kemampuan dan keikhlasan tetapi dilakukan dengan terpaksa di luar batas kemampuan karena gengsi.

\footnotetext{
${ }^{39}$ Disebut saroan atau kobbu'

${ }^{40}$ Pecah dan keluar sehingga membut sumbing sebuah benda.

${ }^{41}$ J Tammu and H. van der Veen, "Longko'," ed. Markus Rani (Toraja Utara: PT. Sulo dan YPKT, June 2016).
} 
Longko', secara heuristika mendidik seseorang agar memiliki harga diri. Selanjutnya harga diri seseorang tentu membutuhan suatu kredensi sosial (pengakuan) dan pengakuan yang dicari orang Toraja pertama-tama adalah berupa pengakuan dari keluarga (terakui sebagai anggota keluarga). Pengakuan sebagai anggota dari persekutuan Tongkonan atau kedudukan dalam Tongkonan. Kredensi sosial sebagai bagian dari kelompok persekutuan adat merupakan nilai yang paling dicari. Pengakuan tersebut mendapat tempat dalam proses pembagian secara khusus ketika nama seseorang diteriakkan/dipublikasi (disa'bu') di tengah kerumunan orang banyak sebagai bagian organik dari komunitas tersebut.

Orang yang sering mengadakan acara untuk memberi makan kepada orang banyak akan mendapat pengakuan dari masyarakat sehingga posisinya dalam urutan pembagian daging bisa naik juga bagiannya daging yang diperolehnya lebih besar. Daging yang dibagikan adalah simbol dan sarana untuk mengakui keanggotaan dan partisipasi seseorang atau sebuah keluarga dalam kehidupan berbudaya dan bermasyarakat. Dengan demikian, ritus-ritus dan berbagai upacara akan membentuk bangunan sikap nilai moral dan etika seseorang untuk menghargai kehidupan sosial. Bahwa egoisme tidak punya tempat dalam kehidupan Tongkonan, bahkan tidak punya nilai dan harga. Jadi seorang anak Toraja tradisional akan mengalami pengedukasian bahwa letak identitas diri sangat bertakaitan dengan komunalitas budayanya (tongkonan).

Pada beberapa wilayah daerah tertentu yang masih kuat dalam pelaksanaan adat Toraja, ternyata menjadikan ritus dan partisipasi dalam upacara adat sebagi bagian yang tak terpisahkan dari semangat dan motivasi kerja mereka. Hal ini didorong oleh keinginan untuk memelihara adat buidaya dan terlebih demi menunjukkan identitas diri dan keluarga di tengah-tengah masyarakat. Karena upacara adat membutuhkan biaya besar, maka orang-orang di beberapa wilayah adat tertentu berusaha menyekolahan anaknya hingga ke perguruan tinggi dengan harapan dapat memperoleh pekerjaan dan penghasilan yang lumayan untuk kebutuhannya sendiri dan pada akhirnya untuk upacara adat. Demikian seterusnya siklus nilai akan teregenerasi melalui edukasi eksperimental dalam penyelenggaraan ritus dan upacara.

Elemen penyembahan kekristenan sering dilihat sebagai ritus yakni liturgy. Elemen agama ini dapat disebut sebagi ritus yang berulang-ulang namun pada dasarnya pola repetisinya turut membentuk karakter umat Kristen. Demikian pun ritus dan upacara dalam budaya tradisional orang Toraja, yang dilaksanakan juga secara perlahan mendidik seorang anak untuk belajar budaya musawarah dan mufakat. Dalam musyawarah untuk mencapai mufakat yang dimenangkan adalah prinsip saling menguntungkan (sikananaran). Orang yang bersifat egois dengan mengeksploitasi sesama/masyarakat, akan tersingkir dari masyarakat. Artinya identitas diri sebagai bagian dari satu komunitas akan terkoyak. Nilai sikananaran mengajari seorang anak 
untuk peduli dan solider pada orang lain. Secara kristiani, setiap orang percaya senantiasa diminta untuk memperhatikan kepentingan orang lain, bukan diri sendiri. "dan janganlah tiap-tiap orang hanya memperhatikan kepentingannya sendiri, tetapi kepentingan orang lain juga" (Fil. 2:4).

Prinsip di atas menjiwai pelaksanaan ritus-ritus dan berbagai upacara baik dalam hal pembagian daging maupun dalam hal berbagi tenaga (saling membantu). Pengabdian kepada sesama, sekaligus berarti kebaikan bagi diri sendiri (sikananaran). Secara universal, heuristika dalam ritus dialami melalui: syair verbal, instrumen tanaman, simbol kerbau dan interaksi sosial yang saling berbagi, lantas menjadi media belajar eksperimental bagi anak yang pengaruhnya sangat kuat serta efektif membentuk identitas diri. Heuristika dalam pemelajaran eksperimental tersebut akan menumbuhkan nilai luhur dalam tradisinya, sekaligus membentuk karakter individu dalam bingkai budayanya sendiri.

\section{Refleksi Teologis}

Bagi komunitas Kristen, nilai tradisi yang ada pada orang Toraja merupakan spirit sosial yang dapat ditransformasi menjadi komunitas kasih yang meletakkan harga diri dan identitasnya pada Yesus Kristus. Harga diri pada komunalitas orang Toraja mesti disempurnakan dengan makna teologis dari simbol Tubuh Yesus Kristus atau keluarga Allah. Pendidikan tradisional orang Toraja menjadi pintu awal untuk melihat bahwa harga diri orang percaya tidak berfokus pada diri sendiri tetapi pada Allah. Dengan demikian, status genealogi ketorajaan lebih diteguhkan oleh status "keluarga Allah", di mana fokusnya bukan pada individu atau komunitas tetapi pada Allah sendiri. Gereja dan setiap institusi Kristen perlu membekali keluarga-keluarga Kristen untuk telaten mendidikkan secara berulang-ulang bahwa status dan identitas kita telah dibaharui di dalam Yesus.

Identitas diri, memang sangat berkaitan dengan komunalitas, namun ide teologis tentang Tubuh Kristus, perlu mengambil bagian penting dalam pemahaman saling bertolong-tolongan serta senasib dan sepenanggungan (sipopa'di') agar perlahan-lahan pengutamaan orang lain dapat memupus egoisme. Hal demikian ini, menjadi karakter yang patut dirawat pertumbuhannya, melalui praktik budaya tradisional yang selanjutnya ditranformasi ke dalam budaya Kristen. Bertolong-tolongan dalam ritus budaya perlu baharui oleh pendidikan Kristen agar tidak berpusat pada utang-piutang, tetapi pada keihlasan dan motivasi saling mengasihi.

Karena itu, secara pedagogis, perlunya upaya untuk mengajarkan terus-menerus bahwa egoisme tidak mendapat tempat dalam kehidupan sosial kemasyarakatan. Dalam keluarga Kristen, anak perlu senantiasa dikondisikan serta dididik menghargai persekutuan (ekklesia) di dalam dunia sosial kemasyarakatan, secara khusus dalam 
gereja sebagai wadah perwujudan shalom. Perihal ini dapat dimulai dengan pertamatama menyemai dan membudayakannya di dalam keluarga kecil sendiri. Maka perlahanlahan kecintaan pada Allah akan mengejawantah dalam kecintaan pada persekutuan dan berkembang menjadi kasih pada sesame manusia tanpa batas dan sekat.

Spirit lebih baik memberi dan menerima dalam tradisi orang Toraja pun memang sudah lebih dahulu dimiliki dalam semangat berkorban. Tindakan yang seolah-olah irasional dalam berkorban dalam rambu solo' membutuhkan kendali dan penuntun dari dalam semangat kekristenan. Sangat dibutuhkan upaya penerobosan dalam pendidikan anak di keluarga-keluarga Kristen (tentu dengan dukungan penuh dari gereja) bahwa korban daging hewan lebih bijak ditranformasi sebagai semangat saling berbagi dan mengakui bahwa segala milik bukan kepunyaan tetapi semata anugerah dan berkat pemberian Allah.

Kalau tindakan yang seolah-olah irasional dalam ritus rambu solo' dibaharui ke dalam persekutun Tubuh Kristus maka dapat dibayangkan bahwa anak-anak Toraja akan mudah dalam menggapai tingkat pendidikan yang baik dan kehadiran orang Toraja akan menjadi berkat di manapun Tuhan mengutus mereka.

Upaya transformasi ekonomi rambu solo' memang sedang terjadi secara perlahan-lahan. Potensi yang perlu dibaharui setiap saat, di mana masih ada beberapa wilayah adat yang melakukan pergorbanan secara "jor-joran” (unggul-mengungguli) tanpa kalkulasi dan agak berdampak negatif. Sementara di beberapa wilayah adat yang sudah mulai mengelola dengan baik menunjukkan kecenderungan baru yang lebih positif.

Beberapa kasus dan wilayah tertentu semangat yang dimiliki oleh kaum protestantisme mewujud dalam motivasi menyekolahkan anak-anak atau generasi muda. Hal ini dilakukan dengan sungguh-sungguh bekerja keras, sanggup hidup sangat sederhana demi keberhasilan pendidikan anak. Motivasi yang mirip spirit protestantisme ini mendorong orang Toraja untuk sanggup dan tahan melakukan proses hidup yang lebih independen secara finansial.

Seseorang yang telah mapan sepatutnya cakap mengidentifikasi kemampuan dirinya sendiri sebagai orang yang telah diberkati oleh Tuhan. Tanggungjawab sosial tesebut bermanfaat untuk menjaga keutuhan persektuan melalui kebersamaan dalam menikmati makanan. Selain itu, seseorang yang sudah mampu dalam masyakarat perlu memerhatikan orang yang miskin sehingga kesenjangan antara yang kaya dan miskin tidak tidak berpotensi menimbulkan konfliks sosial. Dengan kata lain pembagian makanan melalui jamuan bersama dapat memperpendek jarak/gap antara kelas sosial dalam masyarakat. Seorang anak akan menyaksikan sendiri (mentiro) kehadiran orangorang yang telah mapan membagi rejekinya bagi orang lain. Anak terdidik secara natural tatkala mentiro, selanjutnya repetisi dari upacara dan ritus-ritus ini memosisikan anak untuk mengikuti jejak (ma'peolai) kesaksian yang masuk lewat pancainderanya. 
Secara sosial, jika seseorang telah mapan ekonominya maka ia perlu berbagi berkat dengan cara memberi makan bagi orang banyak. Namun, kisah Janda di Sarfat (1Raj.17:7-24; serta cerita 5 roti dan 2 ikan (Mat. 14:13-36), mengajarkan prinsip teologis dari dalam Alkitab bahwa Tuhan bisa memakai orang yang lemah dan tidak diperhitungkan untuk menunjukkan kasih dengan memberi makan orang banyak terutama jika ia tidak mampu.

Perubahan ini tampaknya muncul dari komunitas wilayah adat pada skala kecil, bukan berasal dari Tingkat yang lebih luas. Dapat disimpulkan bahwa perubahan memang lebih ampuh bila dimulai dari komunitas basisi yang lebih kecil. Kunci pendidikan ada pada stakeholder, jadi gereja, pemerintah, budayawan dan segenap insitusi pendidikan mesti bersinergi dalam transformasi budaya dengan menularkan nilai edukasi melalui tradisi di lingkup-lingkup kecil secara berulang-ulang.

\section{Kesimpulan}

Sejatinya, nilai edukasi dalam suatu Tongkonan telah ada sejak zaman primitif orang Toraja, misalnya ketika mereka membagikan daging hasil buruan untuk dinikmati bersama. Budaya pemelajaran eksperimental dalam tongkonan diawali dengan solidaritas kerja dan diakhiri dengan pembagian makanan berupa daging babi dan daging kerbau. Dinamika edukasi seperti ini berlangsung dalam upacara kedukaan maupun upacara sukacita syukuran rumah adat Toraja serta dalam menghadapi pekerjaan-pekerjaan berat. Filosofi pemelajaran yang mendasar dapat ditemukan dalam kultur Toraja yakni diawali dari kerelaan untuk berbagi hasil jerih payah dalam jumlah besar pada orang banyak dan keikhlasan memberikan tenaga untuk membantu orang lain. Selanjutnya, solidaritas dalam berbagi daging dan tenaga dilaksanakan dalam keterhubungan dengan orang lain dalam suatu persekutuan. Hubungan yang menjadi jalan terbangunnya etika komunal dan interaksi sosial adalah persekutuan adat (saroan dan kampung), hubungan genealogis, tongkonan (hubungan kekerabatan yang luas) dan hubungan karena perkawinan. Pendidikan Kristen dapat menimba pengalaman serta belajar dari realitas budaya yang dalam banyak hal memiliki sisi baik kendati selalu perlu dibaharui sebagaimana gereja pun kata Agustinus dan Karl Barth, harus terusmenerus membaharui diri (ecclesia reformata semper reformanda est).

Pada pihak lain, Gereja diberi tanggungjawab untuk selalu mendorong terjadinya perubahan pandangan bahwa pengorbanan tidak mesti berorientasi pada uang, daging atau materi, tetapi tenaga waktu dan kehadiran juga kontribusi yang juga berharga bahkan lebih bernilai dari materi (spirit protestantisme). Prinsip dan integritas diri dibangun melalui simbol makanan dan tenaga yang telah diberikan pada orang lain. Budaya dinamika pemelajaran eksperimental dalam Tongkonan telah dan akan 
mengikat individu atau keluarga dengan persekutuannya. Tongkonan dengan norma dan nilai tradisinya menjadi simbol kolektifitas dan solidaritas masyarakat Toraja menuju pada entitas bangsa yang telah memanusiakan anak-anak tongkonannya melalui edukasi berbasis eksperimental (heuristika).

\section{Referensi}

Agustian, Murniati. Pendidikan Multikultural. Jakarta: Penerbit Unika Atma Jaya Jakarta, 2019.

Bamban, Markus. Ma'kombongan, Desember 2019.

Denok Sunarsi. Dinamika Dan Perkembangan Hypnotherapy Dalam Perspektif Interdisipliner. Edited by Achmad Rozi. Banten: Runzune Sapta Konsultan, 2020. http://eprints.unpam.ac.id/8620/.

Fitriani, Wahyu. "Dongeng Dapat Membentuk Karakter Anak Menuju Budi Pekerti Yang Luhur." Jurnal Review Pendidikan Dan Pengajaran 2, no. 1 (June 12, 2019): 17883.

INDONESIA, Tim Penulis Ikatan Psikologi Perkembangan. Bunga Rampai Psikologi Perkembangan: Memahami Dinamika Perkembangan Anak. Sidoarjo: Zifatama Jawara, 2019.

Jones, Tod. Kebudayaan dan Kekuasaan di Indonesia: Kebijakan Budaya Selama Abad Ke 20 Hingga Era Reformasi. Jakarta: Yayasan Pustaka Obor Indonesia, 2015.

Kobong, Th., ed. Manusia Toraja: Dari Mana - Bagaimana - Kemana. Seri Institut Teologia. Tangmentoe: Institut Teologia Gereja Toraja, 1983.

Kobong, Theodorus. Injil dan Tongkonan: inkarnasi, kontekstualisasi, transformasi. Jakarta: BPK Gunung Mulia, 2008.

Leigh, Ronald, W. Melayani Dengan Efektif. Jakarta: PT. BPK Gunung Mulia, 1996. Magnis-Suseno, Franz. Berfilsafat dari konteks. Jakarta: Gramedia Pustaka Utama, 1991. Nelson, Carl Ellis. Where Faith Begins. Louiseville: John Knox Press, 1971.

Panginan, D. Aluk Bua' Pare. Translated by Y.A. Sarira. 1st ed. Rantepao: Pusbang Gereja Toraja, 2000.

Paranoan, Prof. Dra. Ny. M.S. Aluk Rambu Solo' Upacara Kematian Orang Toraja Analisis Psikososio Kultural. Makassar, n.d.

Paz, Octavio. Levi-Strauss ; Empu Antropologi Struktural. Translated by Landung Simatupang. Yogyakarta: LKiS Pelangi Aksara, 1997.

Polandos, Yan Piter. Heutagogi dalam edukasi kultural Toraja, 2014.

Risyanto, Dwi, and Dyah Kumalasari. Pemikiran Y.B. Mangunwijaya tentang pendidikan sekolah dasar di yogyakarta tahun 1974-1999. Yogyakarta: Jurusan Pendidikan Sejarah Fakultas Ilmu Sosial, 2015. 
http://journal.student.uny.ac.id/ojs/index.php/risalah/article/viewFile/830/75 6.

Riyanto CM, FX. E. Armada. METODOLOGI, Pemantik \& Anatomi Riset Filosofis Teologis. Malang: Penerbit Widya Sasana Publication, 2020.

Sampe, Naomi. "Filosofi Kande Situka' - Analisis Teologis-Sosiofilosofis terhadap Filosofi Kande Situka'dalam Eksistensi Budaya Toraja." STT Kibadi, 2013. ___. "Penilaian Teologis Terhadap Etika Kerja Toraja," 32. Tana Toraja, 2014. Sanderan, Rannu. Exemplary, Menemukan Kunci Pendidikan Iman Bagi Anak Dalam Keluarga Dan Pembelajaran Agama Di Sekolah. Tana Toraja: STAKN Toraja, 2016. Sarira, Y.A. Aluk Rambu Solo'. Rantepao: Pusbang Gereja Toraja, 1996.

Savitri, Poppy. Fungsi lagu pengantar tidur anak dalam proses sosialisasi anak. Jakarta: Departemen Pendidikan dan Kebudayaan, Direktorat Jenderal Kebudayaan, Direktorat Sejarah Dan Nilai Tradisional, Proyek Inventarisasi dan Pembinaan Nilai-Nilai Budaya, 1991.

Susanta, Yohanes Krismantyo. "Tradisi Pendidikan Iman Anak dalam Perjanjian Lama.” BIA': Jurnal Teologi dan Pendidikan Kristen Kontekstual 2, no. 2 (December 30, 2019): 139-50. https://doi.org/10.34307/b.v2i2.127.

Tammu, J, and H. van der Veen. "Lamba'.” edited by Markus Rani, 744. Toraja Utara: PT. Sulo dan YPKT, June 2016.

_—_. "Lellen." In Kamus Toraja - Indonesia, edited by Markus Rani, 744. Toraja Utara: PT. Sulo dan YPKT, June 2016.

——_. "Longko'." edited by Markus Rani, 744. Toraja Utara: PT. Sulo dan YPKT, June 2016.

_—_. “Ola." In Kamus Toraja - Indonesia, 744. Toraja Utara: PT. Sulo dan YPKT, June 2016.

_—_. "Tona'." In Kamus Toraja - Indonesia, edited by Markus Rani, 744. Toraja Utara: PT. Sulo dan YPKT, June 2016.

-_- “Ulele." In Kamus Toraja - Indonesia, edited by Markus Rani, 744. Toraja Utara: PT. Sulo dan YPKT, June 2016.

Tangdilintin, L. T. Toraja Dan Kebudayaannya. Tana Toraja: Yayasan Lepongan Bulan, 1975.

Tilaar, H. A. R. Kebijakan pendidikan: pengantar untuk memahami kebijakan pendidikan dan kebijakan pendidikan sebagai kebijakan publik. Yogyakarta: Pustaka Pelajar, 2008.

Wilcox, Harry. Six Months in Sulawesi. New York, USA: New York University, 1949. 